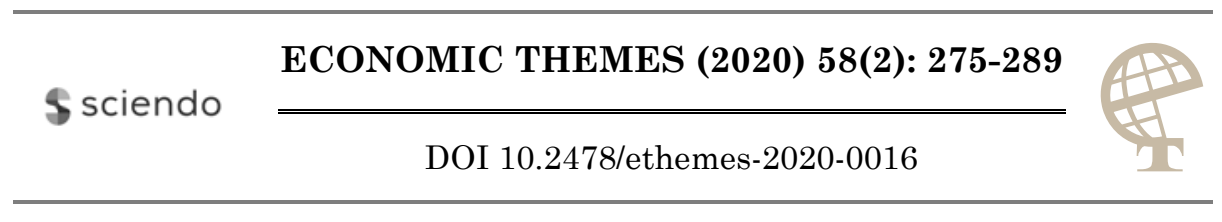

\title{
ATTITUDES OF CHILDREN AND YOUTH ON THE SERBIAN BUSINESS SECTOR
}

\author{
Nataša Krstić \\ University of Singidunum, Faculty of Media and Communications, \\ Department of Media and Communication, Republic of Serbia \\ $\triangle$ natasa.krstic@fmk.edu.rs \\ Danica Čigoja Piper \\ University of Singidunum, Faculty of Media and Communications, \\ Department of Media and Communication, Republic of Serbia \\ $\triangle$ danica.cigoja@fmk.edu.rs
}

UDC

342.7-

053.5:658

Review paper

Received: 06.02.2020 Accepted: 04.05.2020
Abstract: Apart from the increasing attention paid to the role of business in society, with an expanded awareness of the link between the business sector and human rights, over the last decade, there has been a trend of trying to understand the relative impact of businesses on children's rights. After the promotion of the Children's Rights and Business Principles in 2012, the impact of the business sector began to be viewed through the diversity of its possible effects on children in the workplace, the marketplace, in the community or in relation to environmental protection. A quantitative survey of children and young people in Serbia conducted via UNICEF's U-Report platform aiming to test the hypothesis"Are children and youth in Serbia aware of the impact that the business sector has on them?" identified their attitudes that companies can help them in their future development paths, that the greatest area of impact on children's rights comes from the workplace - by providing decent work for young workers and parents and making future jobs more accessible to young people through education and training programmes.At the same time, the expectation of children and youth in Serbia for greater participation of companies in supporting and realising the rights of children in society was emphasised.

Keywords: human rights; children's rights; business impact; Children's Rights and Business Principles; corporate social responsibility; Serbia.

JEL classification: D64, M14. 


\section{Introduction}

Luka (10): "Ivan and Mića will make their YouTube channel, I'll make a logo for them and then we'll sell shirts online." The quote illustrates a common impact that contemporary business practices have on children's minds, in the concrete example, specifically via the new media. Luka and his friends identify with famous online influencers and create their own business plan. Their entrepreneurial spirit is inspired by the developments in the media market which have, in the stead of selling lemonade in front of the school, offered new business models to children which can quickly and easily come to compete with established companies in the market. "Their foremost habit is gathering information by way of modern technologies, competing in digital challenges, along with personal affirmation via popular online channels" (Čigoja Piper, Radojević, Čolović \& Radović, 2019, p. 144), so it can, therefore, be assumed that contemporary industries have a powerful effect on the choices children make; from buying new shoes, obtaining information, to the choice of future profession. Apart from this, business practices of companies worldwide directly or indirectly affect the health of children who use their products or services (Martin-Ortega \& Wallace, 2013). Indirect factors would include those pertaining to manufacturing practices which are not in accordance with ecological standards (Ivanović-Đukić, 2011, p. 23), which in time causes the pollution of air, soil, or water and an array of health problems where children and youth are particularly affected. Direct factors are more conspicuous and refer to the rise in different health problems in children and youth; such as obesity (impacted by unhealthy food), numerous allergies (foods, toys, cosmetics which contain allergenic substances), or addiction to a certain product (video games). However, children are not only consumers of products and services, but many are also "workers in factories and fields, family members of employees and residents of the communities that host operations" (United Nations Children Fund, 2015, p. 8). In that sense, the relationship between the business sector and children should be continuously monitored and advanced in the domain of respecting guaranteed human, or, rather, children's rights.

The development of the agendas of international human rights institutions, led by the United Nations (UN), has also contributed to the developments in the area of children's rights. "Children's rights, just like human rights, are not 'given' to anyone we have them simply by virtue of existing" (Vučković Šahović, 2001, p. 5). The human rights of children are part of many international legal acts and the legal systems of most nation-states. The most significant document which guarantees the rights of children is the UN Convention on the Rights of the Child (1989), and member states in the UN, derive from the Convention laws and other legal acts which actualise and protect children's right "in families, schools, government institutions, workplaces, the streets, and other places and circumstances" (ibid, p. 5). The Convention on the Rights of the Child "legally poses a requirement that the child is in the center of all the activities pertaining to the child and participate in them actively, expressing their opinion" (ibid, 
p. 16). It is precise because of this that it is necessary to devote more attention to the possibility that children could express their attitudes and to research into their opinions because these activities could provide ideas for true changes in the business arena (Berlan, 2016, p. 160) and society as a whole. In the present paper, what the authors particularly find of import is the fact that children are conceived of as thinking subjects who can express their views on a certain topic, and that listening to and respecting children's opinions is legally binding for all other members of society.

\section{Corporate Social Responsibility and Children's Rights}

Considerations of the role and impact of the business sector on the actualization of children's rights have in academic literature mostly referred to topics such as child labour, gender equality and ethics in advertising (Crane \& Kazmi, 2010; Martin-Ortega $\&$ Wallace, 2013). Recent papers highlight the role of corporate social responsibility (CSR) in respecting human rights and their direct relationship to respect for children's rights (Zadek, 2004; Crane \& Kazmi, 2010; Krstić, 2017). In this sense, CSR is defined as a management principle which encompasses four areas of activities: the economic which involves accomplishing the economic goals of the company, the legal - which refers to the obligation to adhere to legal statutes, the moral - which involves the moral obligation towards all stakeholders and the philanthropic - which denotes investment of own resources with the objective of fulfilling higher purposes in the community or society (Carroll, 1991; Ivanović-Đukić, 2011). The role of CSR in the domain of the protection of the human rights of children includes the above stated four areas of managerial activities and involves not only the physical protection of children and ethical business behaviour towards them, but also improving the economic status of the family: the working conditions of the parents, the quality of life, contribution to activities which support education and culture, and others (Crane \& Kazmi, 2010). Thus, CSR can also be considered as a social resource that should contribute to the development of social well-being through the respect of conditions that ensure decent work, sustainable development and environmental protection, through the contribution to government efficiency (Sekulić \& Pavlović, 2018, p. 60).

Along with everything stated above, CSR should also rely on listening to children's needs and opinions and partly organise the conducting of business in accordance with these needs, which would reinforce respect for children's rights in the business sector (Berlan, 2016). The research on the possibilities that CSR could provide to children conducted by the organization Save the Children during 2010 included 150 participants aged between 10 and 18, and the results show that children are able to pinpoint the areas in which the business sector can help them and define the steps to take in order to improve their lives, emphasizing that "they don't want gifts, they want accountability" (p. 9). The problem with the application arises when investment in CSR directed towards child welfare transforms into promotional activities whose purpose is to affirm the product, service or brand, instead of truly exerting a beneficial influence on 
children's quality of life. "With regards to the business sector, social and economic initiatives directed towards children are mostly treated as a reputation management tool and used to shape public opinion of the company as a good corporate citizen" (Krstić, 2017, p. 354). According to Bergadaà (2007), children and youth are directly targeted by companies by way of sophisticated advertising techniques in media, and social criticism problematises CSR precisely by directing attention to the role of marketing and advertising, which are often in collision with ethics.

To enable the systematic introduction of an ethical obligation to respect children's rights in the business sector, UNICEF, Save the Children and United Nations Global Compact have joined their collective expertise in increasing respect for children's rights in various aspects of business practice and developing ten principles that identify the various ways in which the business sector can influence children throughout the entire value chain (2012). The Principles were developed in accordance with the Convention on the Rights of the Child to help companies shape their operations so that they respect and support children's rights through three core areas: the workplace, the market, and the local community with the environment. In concrete terms (ibid, p. 11):

1. Meet their responsibility to respect children's rights and commit to supporting the human rights of children.

2. Contribute to the elimination of child labour, including in all business activities and business relationships.

3. Provide decent work for young workers, parents and caregivers.

4. Ensure the protection and safety of children in all business activities and facilities.

5. Ensure that products and services are safe, and seek to support children's rights through them.

6. Use marketing and advertising that respect and support children's rights.

7. Respect and support children's rights in relation to the environment and to land acquisition and use.

8. Respect and support children's rights in security arrangements.

9. Help protect children affected by emergencies.

10. Reinforce community and government efforts to protect and fulfil children's rights.

By integrating the respect for and support of children's rights in their core business strategies, procedures and activities, companies can strengthen their business sustainability via boosting their reputation, attracting qualified workforce, improving risk management, and securing a social licence to operate (UNICEF et al., 2012; Krstić, 2014).

When it comes to Serbia, the concept of CSR is not fully strategically deployed in local companies as managers often have to "balance between short-term profits and long-term development goals" (Krstić, 2017, p. 3). In addition, it is not uncommon for businesses to reduce their socially responsible practices to philanthropic donations that have a media interest and are considered to be of benefit to the company (IvanovicDjukic, 2011). On the other hand, for companies that put social responsibility in their 
strategic focus and are committed to CSR as a business strategy, the greatest interest exists for projects relating to children. According to the research conducted by UNICEF (2017), the volume of CSR activities towards children is growing year by year and for the majority of responsible companies supporting children (82\%) represents an important segment of social responsibility, while for a third of them $(38 \%)$ children are a priority in their CSR activities. The areas most frequently stated as supported by companies were advancements in formal and informal education $(79 \%)$, public health and healthy lifestyles $(68 \%)$ and improving conditions for life in the local community (64\%). Furthermore, the Serbian Forum for Responsible Business (FRB) conducts annual research on the contribution of its members to sustainable development. According to the findings of the latest research (2018), the five areas most supported by the business sector are education, culture and arts, protection of the environment, sports and social entrepreneurship, with children at the basis of all the activities of their member companies.

It remains unknown whether true respect for reinforcing children's rights in different areas of business is the leading motivation of companies for conducting socially responsible activities, but their increase certainly contributes to respecting and strengthening the rights of children in society.

\section{Research methodology and Hypothesis}

The empirical research was conducted by means of a quantitative research technique via an electronic survey, which was active for a month, between March and April 2019 on the U-Report platform owned by UNICEF in Serbia (serbia.ureport.in). U-Report is a platform collecting data from children and adolescents developed by UNICEF globally for the purpose of advancing the engagement of youth and inciting positive changes in society. The platform sends to logged U-Reporters invitations to participate in surveys (via SMS messaging and social networks), on different social topics such as attitudes towards the media, gender equality, prevention of violence, nutrition, and labour market. This research utilised the platform hosted by UNICEF in order to avoid ethical problems common in research involving children, as it stresses the principle of voluntary participation, establishing a balanced relationship between researcher and participant, respecting the confidentiality of data and maintaining the anonymity of the children participants (Đurić, 2012, p. 457). Additionally, articles 12 and 13 of the Convention on the Rights of the Child (UN, 1989) state that a child capable of forming their own opinion should be accorded the right to freely express this opinion on all the issues that concern them, in accordance with their age and level of maturity, and by way of the medium of choice. In the context of the conducted research, we have defined a child in accordance with Article 2 of the preliminary draft of the Law on the Protection of the Rights of the Child (2019) as every human being between birth and the age of 18, and youth according to the National Strategy for Youth of the Ministry of Youth and Sports (2015) as the category of persons aged 15-30. 
Of the 2,283 registered U-Reporters on the platform, 1,073 users (or 47\%) participated in the survey. Participants were predominantly female $(71 \%)$, from the Belgrade region (48\%) and youth aged 15-19 (65\%), which can be accounted for by the registered structure of U-Reporters. It is important to note that all 24 regions of Serbia targeted by the platform had their representatives in the survey, which ensured national coverage.

In the survey, we started from the stance expressed in the Children's Rights and Business Principles that children are among the most marginalised and vulnerable members of society, as their voices are not sufficiently heard in public. Children are rarely given the opportunity to express their opinion and rarely spoken to when decisions are made in a community. However, when given the chance, children can express interesting alternative opinions and give a valuable contribution (UNICEF et al., 2012, p. 2). Owing to the fact that children are among the main actors in the business sector; as consumers, as family members of the employees, as young workers, as future labour force, business sector leaders and important members of the community and environment in which business is conducted, the hypothesis we wanted to test by way of the conducted survey was:a "Are children and youth in Serbia aware of the impact that the business sector has on them?" Based on the hypothesis, the subject of this paper is examining the awareness and attitudes of children and youth about the direct and indirect impact of the business sector on respect, or violation of their rights. The aims of the research are to (a) determine the extent to which children and youth understand the impact that companies exert on their lives, i.e. respecting, depriving and developing children's rights in Serbia; and (b) based on the research results, give recommendations to improve the CSR in Serbia towards children in accordance with the Children's Rights and Business Principles.

To this end, the participants were asked a single general and five thematic questions out of which four had predetermined answers, while the final question was formulated as open and participants were able to express their personal opinions. The general question was as to the willingness of registered U-Reporters to participate in the survey. The thematic questions in the survey had the aim to test the attitudes of children and youth participating in the research on the impact of companies on their future careers, areas of business which in their view have the greatest impact on the rights of children and activities that companies could take to reduce the gap between themselves, children and youth. Finally, participants were asked to suggest to the business sector ideas, activities and measures that could advance children's rights.

The common denominator for all the questions in the survey was assessing the awareness of children and adolescents of the direct or indirect impact that the business sector has on their rights, in the sense of their deprivation or advancement. For the purposes of obtaining a better overall view of the research results, the findings were cross-referenced with recent researches on the investments and areas of support to CSR towards children (UNICEF, 2017; Forum for Responsible Business, 2018). 


\section{Research results and discussion}

Do children and young people think that companies have a positive view of their future development path and the role they play in the Serbian economy? In the present research, the question of whether companies can help youth in their future careers is dominated by positive responses (68\%). Namely, close to half of the survey participants (42\%) believe that the business sector can partially help the youth, but the focus still puts its own business objectives, while about one third (26\%) believe that businesses have the capacity to help young people in their future careers (Fig. 1). Fewer participants responded that companies either were not able, to or did not want to help children and youth in their future development (19\%).

Figure 1. "Do you think that companies can help youth in their future careers?"

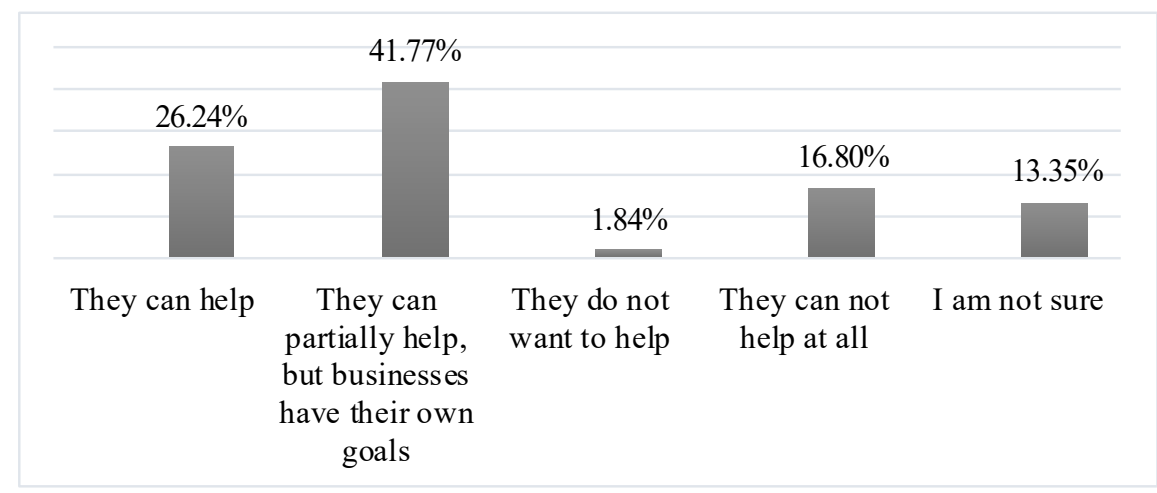

Source: research by the authors

In the view of children and youth who participated in the conducted research, by far the greatest area of impact that the business sector has derived from the workplace $(87 \%)$, by way of securing decent jobs for young workers and parents $(75 \%)$ and protecting the safety of children in all business activities (12\%). These findings are expected considering the state in the job market where the majority of employees earn minimum wage salaries (FREN, 2019, p. 67), and that the rate of informal employment, though decreased in the last several years, is still high at around $20 \%$, which means that a fifth of all workers in Serbia are informally employed (ibid, p. 65). Additionally, the probability of unemployment among youth (15-24) is almost three times that of the adult population (25-54) (EBRD, 2017, p. 16), making the unemployment youth rate as high as around $24.4 \%$, i.e., a quarter of youth in Serbia is unemployed (SORS, 2019). Even among university graduates, the unemployment rate is much higher than in the European Union; 15\% compared to 5.6\% (EBRD, 2017). Besides, The ambience where young people can be stimulated to start their own business is not developed enough in Serbia (Đorđević, Ćoćkalo \& Bogetić, 2010). According to the survey participants, other areas of impact for the business sector on 
children's rights are far less represented, such as safety products and services, respect for children in advertising and regarding the environment (Fig. 2). In the open-ended response, the participants additionally reinforced the area of impact by way of the workplace, stating the importance of the parents' job security ("parents to have a secure job", "decent salaries for parents"), advocating for better employability of youth workers ("companies to strive for better possibilities of youth employment") and decent work conditions which value youth workers ("companies to motivate creativity and innovation in youth workers, to take into consideration their principles and suggestions").

Figure 2. "Which is the area in which companies should primarily support the rights of children and youth, directly or indirectly?"

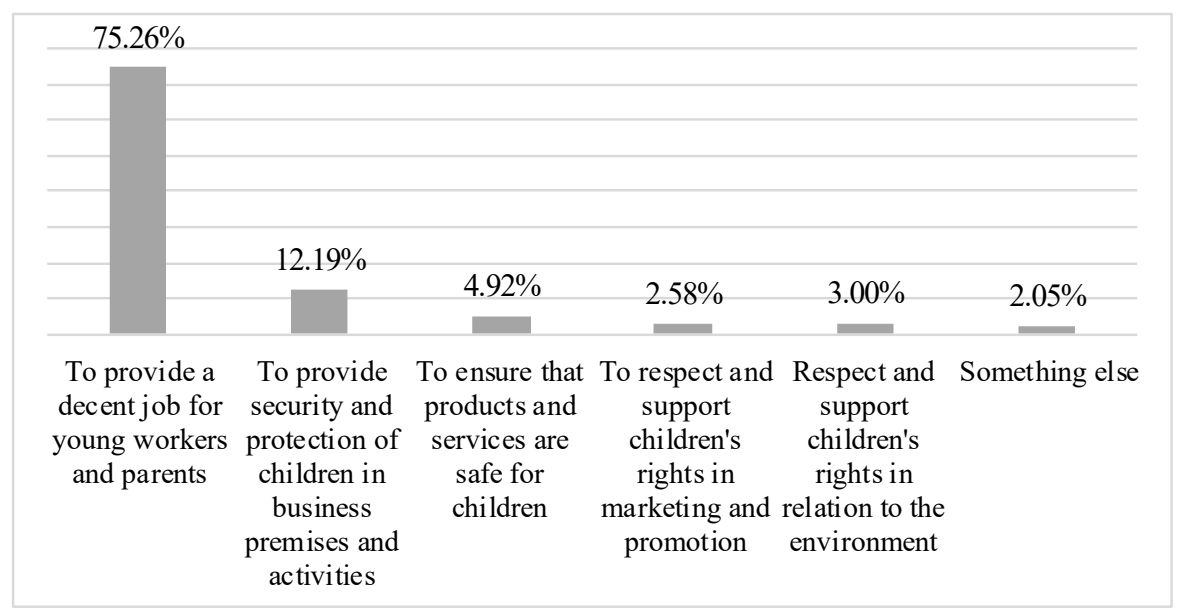

Source: research by the authors

Children and youth who participated in our research suggested several additional measures and areas in which companies could support them, prominent among which were greater respect for children's rights (33\%), financial support to organizations and institutions supporting children (28\%) and preserving the environment (25\%) (Fig. 3). We can conclude that children and youth do not consider companies to be sufficiently engaged and active in honoring and protecting children's rights, based on the fact that a full third of the participants thought that greater engagement of the business sector was needed in this area. Also, financial support given by socially responsible companies to children in the form of sponsorships and donations is insufficiently visible to this target group, since nearly a third of the participants in the present research believe it should be improved (28\%). The same conclusion can be made with regard to preserving the environment, which a quarter of the participating children (25\%) stress as a desirable additional measure of engagement by the business sector, whereas earlier research (UNICEF, 2017; FRB, 2018) indicates that this is an area into which companies gladly 
invest and which they are prepared to support in the future as well. Regarding aiding children in emergencies, additional measures are not needed in the opinion of children and youth who participated in our research (only $7.4 \%$ pointed out this area). This result can be seen in relation to the results of the research conducted by UNICEF, which shows that only $38 \%$ of companies have an action plan regarding children in case of emergencies. A common denominator for both socially responsible companies and for children and youth is the fact that they do not see support for certain vulnerable groups (children from minority communities, at-risk/in the streets) as an important area of support. Only $7 \%$ of children and youth from our research emphasised this area, while as many as $76 \%$ of companies from the UNICEF research showed no interest or partial interest in financing services and programmes for the most vulnerable groups of children.

Figure 3. "Which additional measure should companies take to have a more positive impact on children and youth?"

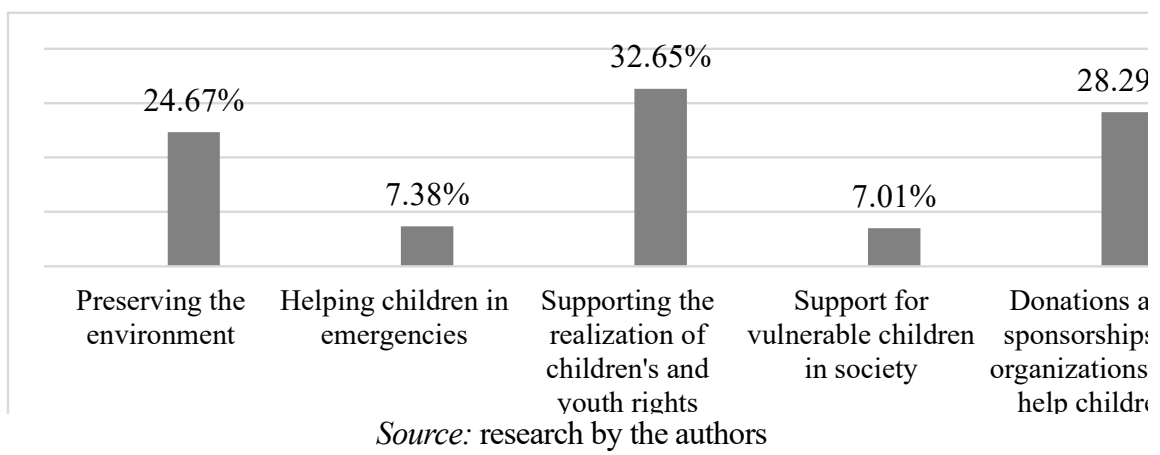

The EBRD has in its analysis of the Serbian economy (2017, p. 5) recognised youth employment and investments into education as the leading initial motivation which could advance the productivity of the economy. The same report states that the competitiveness of the Serbian economy is negatively impacted by the discrepancy of the business skills that youth offer in the job market, as the educational system and obtained knowledge, do not match the demand in the market expressed through the needs of the private sector (ibid, p. 11). Therefore, it doesn't surprise that over half of children and youth (56.5\%) participating in our research believe that companies should make additional efforts through organising work experiences, mentorships, internships and volunteer work, in order to make the work environment more approachable to them (Fig. 4). Also, above a third of the participants in our research (32\%) stress the importance of student scholarships which could indirectly reduce the brain drain Serbia struggles with, and which costs the state up to 1.2 billion euros per annum (Institute for Development and Innovations, 2019). It can be concluded from the above that the youth workforce is crucial to future sustainability and development potential of the 
Serbian economy, reflected in its increased productivity and competitiveness as well as the offer of a qualified workforce in the job market.

Figure 4. "Which step should companies make to create the business environment more approachable to youth?"

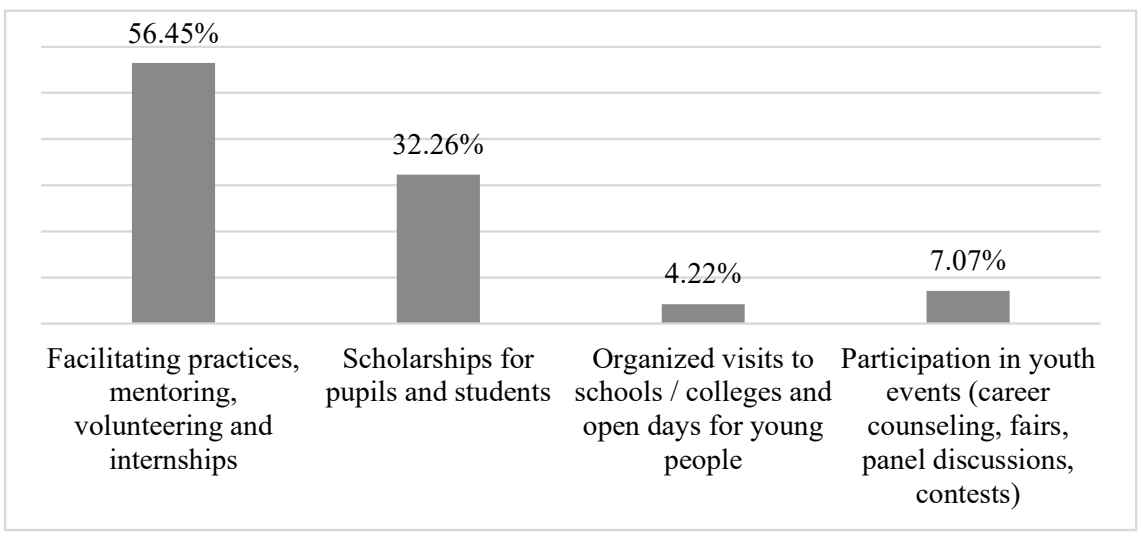

Source: research by the authors

The final, open-ended question asked for suggestions from children and youth as to what the business sector could do to better support the rights of children ("What do you suggest companies should do to support the rights of children and youth in society?"). The aim of the open-ended question was to give the research participants an opportunity to express their personal views on the impact of the business sector on children and youth, considering the fact that the research approach which studies children from the position of their own attitudes, views, and perception advances the rights of children in its very foundations (Đurić, 2012). Based on an analysis of responses given by 642 research participants, the findings from the previous research questions were reinforced as follows:

- the area of greatest impact for the business sector derives from the workplace ("companies should start offering decent salaries and secure positions"; "companies should stop being slaveowners towards my parents"; "secure decent, instead of humiliating working conditions for young workers, so they can attain experiences");

- companies are insufficiently active in advocating for the rights of children in society ("they should interview children and youth about their ideas, and help them achieve their goals"; "they should establish actual contact with children and youth in order to better listen to their needs"; "to fight for young people"; "to become more involved in campaigns which support the rights of children and youth");

- activities in the area of environmental protection should be more intense and visible ("to save nature, not use plastic"; "children have the right to live in a clean, 
healthy, unpolluted environment"), as should be the support to organizations and institutions which support children ("to become involved in numerous activities performed by children and young people and organised by schools");

- companies are not taking additional efforts to make the business environment more approachable to future workers ("they should enable more work experiences so young people could gain an idea of what they would like to do in their lives"; "open office days with a practical segment"; "not to discriminate against young people interested in working").

\section{Conclusion}

The connection between the business sector and children appears to be growing more intense. Children encounter different business practices daily as consumers, family members of employees or company owners, young workers or participants in company educational programmes, supporting the activities of the business sector. Children are therefore key actors in doing business, not only on account of being under the influence or business activities and relationships but also because they represent future employees and managers in companies and consumers of their products and services. The conducted research attests to this, confirming that companies in Serbia have a powerful and clearly visible impact on the lives of children and youth.

The tested hypothesis was disproved by the responses our participants gave to questions concerning various areas in which the business sector exerts a direct or indirect impact on the quality of their lives. In that respect, the first aim of the paper is attained and presented in the conclusion that children and youth in Serbia are fully aware of the impact that the business sector has on them. During the analysis of the obtained results, it was determined that companies can help youth in their future careers and that the area of greatest influence on children's rights was via the workplace - by securing decent jobs for young workers and parents and making the future workplace approachable to young workers, and that more involvement of companies in supporting and actualising children's rights in society is desired.

Insight into how children and youth interpret the impact that companies have on their lives leads to recommendations on how to improve the CSR of companies in Serbia in the area of children's rights in accordance with the Children's Rights and Business Principles:

- for Principles no. 1 and no. 10, which speak to the aim of raising awareness on the rights of children and the obligation to respect them, the participants in the research opined that it is necessary for companies to establish real contact with children and youth, to research their needs and act in accordance with these findings to initiate campaigns which will directly and clearly endorse children's rights, and to support organizations and institutions which support children; 
- in order to actualise Principle no. 3 which secures decent work for young workers, parents and guardians, children and youth in Serbia stress the necessity of respecting the basic rights of employees with regard to paying a proper salary and payroll taxes, the need to introduce a "family-friendly" work atmosphere and making the future workplace more approachable to young workers through different educational and training, as well as short-term programs for talented youth;

- the area of the environment (Principle no. 7) must be promoted and respected more effectively, by way of a larger number of visible activities striving to preserve the nature (promoting recycling, conducting projects for children and youth which incite a responsible stance towards nature);

- finally, children and youth should be treated as a group of stakeholders demanding special attention. Including children in advancing the social community and ecological initiative of the business sector do not only represent initiatives earning the epithet of "good corporate citizen" but also carry potential risk to companies' reputations (S̆maižienè, 2015); this is why it is necessary to conduct a sequence of strategically planned activities which would bring long-term benefits to children and youth, but also to the company as a whole.

The listed recommendations can be incorporated into business strategies, however, many CSR activities, including one related to children's rights, are neglected, for which the human factor might be accountable - the management. According to Kumaza (2018), social responsibility of companies usually encompasses all the issues of importance to society, but frequently "managers lack the knowledge and understanding of business externalities" (p. 209). In that sense, it is necessary that the government, non-governmental organisations and media secure the advocacy of CSR activities which relate to the strengthening and promotion of children's rights, along with their more active supervision, reinforcing their initiative with managers and company owners. Additionally, introducing the Children's Rights and Business Principles into business strategies, policies and procedures would be achievable if they were incorporated in CSR or sustainability reports, if their introduction were endorsed by a reputable and comprehensive business association (such as the Serbian Chamber of Commerce) or via certification of socially responsible companies (Krstić, 2017).

A limitation the authors encountered during the research is reflected in the insufficient involvement of children and youth in actively taking part in discussions about the topics and fields of interest that impact them, like the business sector. Despite utilising the U-Report platform, out of the 2,283 registered U-Reporters, 1,073 confirmed their willingness to participate. However, valuable findings were obtained on the attitudes of children and youth on the direct and indirect impacts that the business sector in Serbia has on them, which to this day represents an unexplored area in national academic research. Future research on this topic could intersect in-depth opinions of children and youth with companies by using focus groups, which would pinpoint with greater clarity the areas of Child Rights and Business Principles where there is a need for additional involvement of the business sector. 


\section{References}

Bergadaà, M. (2007). Children and Business: Pluralistic Ethics of Marketers. Society and Business Review, 2(1), 53-73. DOI 10.1108/17465680710725272.

Berlan, A. (2016). Whose Business is it Anyway: Children and Corporate Social Responsibility in the International Business Agenda. Children \& Society, 30, 159-168. DOI:10.1111/chso.12149.

Carroll, A. (1991). The Pyramid of Corporate Social Responsibility: Towards the Moral Management of Organizational Stakeholders. Business Horizons, 4(3), 1-20. https://doi.org/10.1016/00076813(91)90005-G.

Crane, A. \& Kazmi, B. A. (2010). Business and Children: Mapping Impacts, Managing Responsibilities. Journal of Business Ethics, 91(4), 567-586. DOI: 10.1007/s10551-0090132-y.

Čigoja Piper, D., Radojević, T., Radović, N. \& Čolović, M. (2019). Uloga medijske konvergencije u razvoju kulturnih i kreativnih industrija. In Proceedings of the International Scientific Conference on Information Technology and Data Related Research - Sinteza 2019 (pp. 141146). Novi Sad: Singidunum University. DOI: 10.15308/Sinteza-2019-141-146.

Đorđević, D., Ćoćkalo, D., \& Bogetić, S. (2010). Preduzetničko ponašanje kod mladih -- rezultati istraživanja u Srbiji. Ekonomske teme, 48(3), 467-479.

Đurić, S. (2012). Etički problemi u istraživanjima o deci. Specijalna edukacija i rehabilitacija, 11(3), 449-468. doi:10.5937/specedreh11-2552

European Bank for Reconstruction and Development. (2017, December). Serbia Diagnostics: Assessing Progress and Challenges in Developing a Sustainable Market Economy. Prepared by Economics, Policy and Governance Department at the EBRD.

Forum for Responsible Business (2018). Doprinos kompanija članica Foruma za odgovorno poslovanje održivom razvoju u 2017. godini. Belgrade: Smart kolektiv.

Fondacija za razvoje ekonomske nauke (2019). Kvartalni monitor 57, retrieved from: http://www.fren.org.rs/sites/default/files/qm/osvrt1-57.pdf, accessed 19 September 2019.

Institut za razvoj i inovacije - IRI (2019). Troškovi emigracije mladih, retrieved from: http://iri.rs/uploads/documents/troskovi-emigracije-mladih.pdf, accessed 28 October 2019.

Ivanović-Đukić, M. (2011). Podsticanje društveno odgovornog poslovanja preduzeća u funkciji pridruživanja Srbije EU. Ekonomske teme, 49(1), 45-58.

Krstic, N. (2017). Primena Principa poslovanja i prava dece u strategiji društveno odgovornog poslovanja preduzeća u Srbiji. Sociologija, 59(3), 351-363. https://doi.org/10.2298/ SOC1703351K

Krstić, N. (2014). Razvoj društveno odgovornog poslovanja kao deo poslovne strategije preduzeća u Srbiji. Doctoral dissertation, Faculty of Economy, Finance and Administration, Singidunum University, Belgrade, Serbia.

Kumaza, A. (2018). Examining Business Innovation in the Social Responsibility. Ekonomski horizonti, 20(3), 197-213. UDC: 33 ISSN: 1450-863 X.

Martin-Ortega, O., \& Wallace, R. (2013). Business, Human Rights and Children: The Developing International Agenda. Denning Law Journal, 105-128.

Ministarstvo omladine i sporta Republike Srbije (2015). Nacionalna strategija za mlade za period od 2015. do 2025. godine, retrieved from: https:/www.mos.gov.rs/mladisuzakon/ attachments/article/389/nacionalna_strategija_za_mlade0101_cyr.pdf, accessed 17 October 2019.

Ministry of Labor, Employment, Veteran and Social issues of the Republic of Serbia (2019). Draft Law on the Rights of the Child and Child Ombudsman, retrieved from: https://minrzs.gov.rs/arhiva-internet-prezentacije-

2019/images/prednacrt_zakona_o_pravima_deteta_i_zastitniku_prava_deteta.doc, accessed 1 December 2019. 
Save the Children (2010). Children's participation in Corporate Social Responsibility, retrieved from: https://www.business-humanrights.org/sites/default/files/reports-and-materials/Childrenparticipation-in-CSR-Jun-2010.pdf, accessed 1 October 12019.

Sekulic, V., \& Pavlovic, M. (2018). Corporate Social Responsibility in Relations with Social Community: Determinats, Development, Management Aspects. Ekonomika, 64(4), 59-69. https://doi.org/10.5937/ekonomika1804057S

Šmaižienè, I. (2015). Children-Engaging Social and Environmental Initiatives as Determinants of Corporate Reputation. Enterpreneurial Business and Economics Review, 3(4), 89-103. DOI: 10.15678/EBER.2015.030406.

Statistical Office of the Republic of Serbia (2019). Developments in the labor market in the second quartal of 2019, retrieved from: http://www.stat.gov.rs/en-us/oblasti/trziste-rada/anketa-oradnoj-snazi/, accessed 29 September 2019.

Vučković Šahović, N. (2001). Prava deteta i Konvencija o pravima deteta, Belgrade: The Yugoslav Center for the Rights of the Child.

United Nations (1989, November 20). Convention on the Rights of the Child, retrieved from: https://www.unicef.org/serbia/media/3186/file/Konvencija\%20o\%20pravima\%20deteta.pdf , accessed 17 October 2019.

UNICEF Serbia (2017). A report on the state of CSR towards children (Izveštaj o stanju društveno odgovornog poslovanja sa fokusom na decu). Belgrade: Serbia.

UNICEF, The Global Compact and Save the Children (2012). Principi poslovanja i prava deteta, retrieved from: https://www.unicef.org/serbia/sites/unicef.org.serbia/files/2018-06/principiposlovanja-i-prava-deteta.pdf, accessed 8 November 2019.

UNICEF (2015). Obligations and actions on children rights and business, retrieved from: https://www.unicef.org/csr/files/CSR_GC_OBLIGATIONS_AND_ACTIONS_FINAL_AU GUST05.pdf, accessed 19 October 2019.

Zadek, S. (2004). The Path to Corporate Responsibility. Harvard Business Review, 82(12), 125-132.

\section{STAVOVI DECE I MLADIH O POSLOVNOM SEKTORU SRBIJE}

Apstrakt: Pored sve veće pažnje koja se posvećuje ulozi biznisa u društvu, uz uvećanu svest o vezama između poslovnog sektora i ljudskih prava, u poslednjoj deceniji je aktuelizovano sagledavanje relativnog uticaja poslovnog sektora na prava dece. Nakon promocije Principa poslovanja i prava dece u 2012. godini, uticaj poslovnog sektora počeo je da se posmatra kroz raznovrsnost načina na koji utiče na decu, na radnom mestu, tržištu, u zajednici i naspram očuvanja životne sredine. Kvantitativno istraživanje dece i mladih u Srbiji sprovedeno preko UNICEF-ove platforme U-izveštaja sa ciljem da se ispita hipoteza „Da li su deca i mladi u Srbiji svesni uticaja koji poslovni sektor ima na njih?" identifikovalo je njihove stavove da kompanije treba i mogu da im pomognu na budućem razvojnom putu, da najveća oblast uticaja na dečja prava dolazi sa radnog mesta - omogućavanjem dostojnog rada mladim radnicima i roditeljima i čineći buduća radna mesta mladima dostupnim kroz programe obrazovanja i obuke. mesta mladim radnicima. Ujedno, istaknuto je i očekivanje dece i mladih u Srbiji o većem učešću preduzeća u podršci i ostvarivanju prava dece u društvu.

Ključne reči: ljudska prava; prava dece; poslovni uticaj; Principi poslovanja i prava deteta; društveno odgovorno poslovanje; Srbija.

\section{Acknowledgement}

The U-Report platform for the research was provided by the United Nations Children Fund (UNICEF) in Serbia 


\section{Authors' biographies}

Nataša Krstić is Associate Professor at the Faculty of Media and Communications, Singidunum University and Head of the Digital Marketing curriculum. She graduated and received her master's degree from the Faculty of Economics, University of Belgrade and obtained her $\mathrm{PhD}$ in Management Sciences in 2014 at Singidunum University. In 2015, she received the "Professional Diploma in Digital Marketing" awarded by the renowned UK Institute of Direct and Digital Marketing (IDM). In 2016, she also specialized in Search Engine Optimization (SEO) at the University of California - UC Davis. Her areas of research are digital marketing and corporate social responsibility.

Danica Čigoja Piper is Assistant Professor at the Faculty of Media and Communications, Singidunum University. She has developed her research in media studies, with special emphasis on critical analysis of media content. She has published extensively and served as a junior researcher in two international academic projects (RRPP and IMPULSE). She is an accredited educator for teacher trainings in high schools approved by the Ministry of Education, Science and Technological Development of the Republic of Serbia. 